\title{
Egy zselici löszmélyút fullánkos (Hymenoptera, Aculeata) fajai
}

\author{
JóZAN ZsOLT
}

H-7453 Mernye, Rákóczi u. 5., Hungary, email: jozan.zsolt@citromail.hu

\begin{abstract}
JózAn, Zs.: Aculeata species (Hymenoptera, Aculeata) of a loess road in the Zselic hills, SW Hungary.
Abstract: In this paper, the author documented the Aculeata species of a loess road in the Zselic hills (SW Hungary). Table 1 shows the number of species per family comparing to other protected area. The number of cleptoparasite species is large. The proportion of Chrysididae, Pompilidae and Halictidae species is significant. The proportion of widespread species is $50-55 \%$, that of Mediterranean wasps $34 \%$ and that of bees only $26 \%$. $55 \%$ of the wasps and $46 \%$ of the bees are eremophilic. Rare species are Chrysura trimaculata, Omalus biaccinctus (Chrysididae), Agenioideus usurarius, Ceropales pygmaea, Entomobora crassitarsis, Priocnemis pogonioides (Pompilidae), Passaloecus borealis, Passaloecus brevilabris, Passaloecus pictus (Crabronidae), Amegilla magnilabris, Amegilla quadrifasciata, Nomada bispinosa, Nomada mutabilis, Thyreus histrionicus (Apidae), Lasioglossum pseudocaspicum (Halictidae), Coelioxys acanthura, Hoplitis tergestensis, Megachile albisecta (Megachilidae)
\end{abstract}

Keywords: Aculeata, host, cleptoparasite, nesting, loess road, rare species

\section{Bevezetés}

A több évtizedes faunisztikai kutatásaink során számos alkalommal dolgoztunk DélDunántúl löszvidékein Külső-Somogyban, a Tolnai-hegyháton és a Zselicben is. Sok helyen gyüjtöttük löszmélyutak, löszpartok fullánkos fajait. Tapasztaltuk, hogy jellegzetes fajegyüttesek élnek itt. Ezek között a legjelentősebbnek egy szentbalázsi löszmélyút mutatkozott. Tevékenységünket Móczár László klasszikusnak mondható vizsgálatai is motiválták, melyeket a Tihanyi-félszigeten a Csúcs-hegy oldalában lévő löszparton folytatott. Ez az Odynerus spiricornis kürtősdarázs faj viselkedésének részletes megfigyelésére irányult (Móczár L. 1960, 1961). Sajnos a löszmélyutak sokfelé szukcessziós folyamatok következtében átalakulnak, beárnyékosodnak, fullánkos faunájuk elszegényedik, diverzitásuk csökken. Ez történt például Szenna (Észak-Zselic) földtani szempontból is jelentős löszfeltárásánál. Ez is indokolja az ilyen helyek faunisztikai vizsgálatát. 


\section{Anyag és módszer}

A vizsgált löszmélyúton Szentbalázs község (Dél-Dunántúl, Zselic) központjából a községi szőlőket és szántókat lehet megközelíteni. Ennek egy 175 méter hosszú szakaszán végeztük a gyüjtéseket. (Közepének koordinátái: 46²19'19"N 1753'44"E). Ennek alsó egyharmada árnyékos, fákkal és cserjékkel szegélyezett. A felsőbb kétharmada napsütötte, mélysége 2-3 méter között váltakozik. Délelött a nyugati, délután a keleti partoldalát éri a napfény 2-3 óra időtartamig. A nyugati oldalon a mélyút mellett közvetlenül a község temetője van, keletről pedig egy legelőnek használt gyepterület található. 2004-től 2020-ig 34 alkalommal végeztünk egyelő-hálózó gyüjtéseket. Emellett figyelembe vettünk néhány ritka, 1970-es és 80-as években itt fogott fajt is. Egy-egy alkalommal 45-60 percet töltöttünk a helyszínen. A gyüjtéseket a szerző és Sasvári Mária végezte. A publikáció nem tér ki a Formicidae, Bethylidae, Dryinidae és Embolemidae családokra.

\section{Eredmények és értékelés}

A vizsgált löszmélyút jól reprezentálja Dél-Dunántúl lösztájain sokfelé kialakult mélyutak és löszpartok fullánkos fajegyütteseit. A gyüjtések során figyelembe vett terület a faunisztikai kutatások szokásos kiterjedéséhez viszonyítva nagyon kicsiny. Ennek ellenére tekintélyes az elökerült fajok mennyisége (285 faj), ám figyelembe kell venni a gyüjtési alkalmak jelentős számát is.

Az egyes kutatott területen előkerült fajok számát összehasonlítva megállapítható, hogy Szentbalázson jelentős a Chrysididae-, Pompilidae- és Halictidae fajok részesedése, a Crabronidae-, Andrenidae- és Melittidae fajok számaránya pedig alacsony (1. táblázat). Az itt megtalált Chrysis fajok mindegyikét gyüjtöttük számos falusi településen, vályogfalakon és sárhabarcsos téglafalakon is, de az ezeken szinte mindenütt előkerült Chrysidea disclusa fajt a szentbalázsi löszfalon nem találtuk meg. Az Elampini- és Chrysidini tribus fajszáma gyakorlatilag megegyezik.

A hazánkban kimutatott fajszámokhoz viszonyítva itt a Hedycrum fajok száma jelentős, ellenben kevés Hedychridium faj került elö. Ez összefüggésben van a gyakoriságukkal is.

Az Omalus s.l. fajok nem földben fészkelő (terricol) állatok. Arboreális élőhelyeket preferálnak. Ennek tulajdonítható, hogy ezek közül itt csak kettő került elö, és csak egykét példányban. A Hedychrum fajok példányait a nyári gyüjtési alkalmak többségében megfogtuk.

A Pompilidae fajok változatossága jelentős mértékü. A 25 faj 13 genuszba tartozik. Közülük az Anoplius genusz tünik ki, a hazai fajok majdnem felét megtaláltuk. Mindhárom hazai Auplopus faj előkerült. Ezek a leggyakoribb Pompilidae fajok a löszpartokon, vályogfalakon. Az Anospilus orbitalis, Aporus pollux és a Dicyrtomellus tingitanus kifejezetten meleg- és szárazságkedvelő. Az Entomobora crassitarsis és a Priocnemis pogonioides jelentős színező faunaelem.

A Vespidae fajok számaránya átlagosnak bizonyult. A legnépesebb genusz az Eumenes. A Magyarországról ismert fajok közel fele előkerült. A löszfalak két jellemző faja az Antepipona deflenda és az A. orbitalis megtalálható, ám a Zselicben másutt sokfelé elökerült Jucancistrocerus jucundus itt még nem gyüjtöttük. Ebben a családban faunisztikai szempontból jelentősebb fajt nem találtunk.

A négy Sphecidae faj a többi vizsgált területtel összehasonlítva átlagosnak mondható. A Sceliphron curvatum feltételezhetően a pókzsákmányt keresve bukkant fel a löszpartnál, a másik négy faj fészeképítés céljából. 
A Crabronidae fajok részaránya az átlagosnál alacsonyabb ugyan, de a Pemphredoninae alcsalád fajainak részaránya elég jelentős. A Diodontus és Passaloecus fajok a löszbe vájt járatokban fészkelnek, ezek teszik ki az alcsalád fajainak több mint felét. Faunisztikai szepontból egyaránt jelentős a Passaloecus borealis, P. brevilabris és a $P$. pictus.

A Crabroninae alcsalád fajainak részaránya átlagos. Túlnyomó többségük talajlakó, a löszparton fészkel. A 19 Magyarországról ismert Ectemnius faj közül csak az E. dives került elö. Ezek korhadó fák, cölöpök elhagyott bogárjárataiban fészkelnek. A Solierella compedita növényi szárakban is helyez el lárvafészket. Ezek feltételei a közelben találhatók meg. A Cerceris fajok a talajban készítik a fészekjárataikat, a löszpartok ideális élőhelyet biztosítanak számukra. Nem meglepő, hogy a hazai fajok egyharmada előkerült a vizsgált területünkön.

A méhek (Anthophila) közül a legalacsonyabb részesedést az Andrena fajok esetében tapasztaltuk. A magyarországi fajok mindössze 14\%-a került innen elö. A fajok talajban fészkelnek, de többségük üdébb gyeptársulásokban, erdők gyepszintjében él. A gyüjtött méhfajok egynegyede az Apidae családba tartozik. Ez a fajszám a hazai Apidae fajok egyötödét teszi ki. A fajok nagy része szintén terricol, kivételt a Xylocopinae alcsalád képez. A legjelentősebb a Nomada genusz. A hazánkban kimutatott fajok majdnem egynegyede előkerült. Ez azért érdekes, mert a gazdaállat Andrena fajok száma meglehetősen alacsony. A domináns faj a Nomada distinguenda volt, ami minden nyári gyüjtési alkalommal jelentős egyedszámban repkedett a falon.

Az Apidae családban még további öt fészekparazita nem fajait sikerült megtalálni: Biastes, Melecta, Pasites, Thyreus és Triepeolus. Az ilyen életmódú fajok száma a családban meghaladja az 50\%-ot, hasonlóan a magyarországi teljes faunához.

Feltételezhető gazdaállat - cleptoparazita párok: Amegilla quadrifasciata - Thyreus histrionicus, Amegilla salviae - Thyreus ramosus, Anthophora plagiata - Melecta albifrons, Pasites maculatus - Nomiapis diversipes.

A Colletidae fajok az összes fajszámból való részesedése átlagos. A Colletes inexpectatus sok löszparton telepekben fészkel (például a Kaposvár környéki Szenna határában), ám itt számottevő fészektelep nem alakult ki. A Hylaeus fajok közül a $H$. leptocephalus a leggyakoribb fészkelő a löszfalakon, vályogfalakon.

A vizsgált területen a legnépesebbnek a Halictidae család bizonyult. A méhfajok egyharmada ebbe a taxonba tartozik. A magyarországi Lasioglossum fajok egyharmada, a Sphecodes fajoknak pedig több mint fele előkerült itt. A család fajai a talajba ásott járatokban készítik el a lárvabölcsőiket. A Sphecodes genusz fajai a többi Halictidae fészekparazitája. A löszmélyút ideális fészkelőhely, ezért a cleptoparazita méhfajok jelenléte intenzív. A Megachilidae fajok részaránya a többi, a táblázatban feltüntetett területhez hasonlítva átlagos. 5 Megachile és ugyanannyi Coelioxys faj került elö. Ezek gazdaállatfészekparazita kapcsolatban vannak. Feltételezhető párok: Megachile albisecta Coelioxys acanthura, Megachile pilidens - Coelioxys afra, Megachile willughbiella Coelioxys conoidea.

A darázsfajok mintegy 50\%-a széles elterjedésü (holarktikus, palearktikus, nyugatpalearktikus és euroszibériai). A méhfajok esetében ez az arány eléri az 55\%-ot. A mediterrán elterjedési jellegű fajok részesedése a darázsfajok esetében 34\%, a méheknél pedig 26\%. Az európai faunaelemek részaránya mindkét csoportban $15 \%$ körüli. A melegkedvelő fajok (eremophil) aránya a darázsfajok esetében 55\%, a méheknél 46\%. A széles türéshatárúaknál (hypereuriök) a különbség a két csoportnál valamivel kisebb: darazsak 31\%. méhek 34\%. A hüvösebb, nedvesebb élöhelyeket kedvelöknél (hylophil) már jelentősebb a különbség, a darazsak esetében 14\%, a méheknél $20 \%$. 
1. táblázat: Szentbalázson és néhány más vizsgált területen előkerült Aculeata fajok száma családonként

\begin{tabular}{|c|c|c|c|c|c|c|c|}
\hline Családok & 氖 & 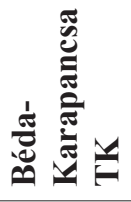 & 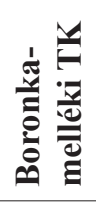 & 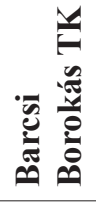 & 氞 & 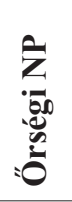 & 㫐 \\
\hline Chrysididae & 23 & 19 & 36 & 28 & 30 & 25 & 36 \\
\hline Sapygidae & 1 & 2 & 2 & 1 & 0 & 2 & 1 \\
\hline Tiphiidae & 1 & 1 & 5 & 3 & 4 & 2 & 2 \\
\hline Mutillidae & 2 & 4 & 7 & 7 & 7 & 4 & 5 \\
\hline Scoliidae & 1 & 1 & 2 & 2 & 3 & 0 & 2 \\
\hline Pompilidae & 25 & 14 & 50 & 35 & 34 & 25 & 25 \\
\hline Vespidae & 19 & 27 & 35 & 24 & 19 & 34 & 26 \\
\hline Ampulicidae & 0 & 0 & 0 & 1 & 0 & 1 & 1 \\
\hline Sphecidae & 5 & 3 & 7 & 9 & 10 & 4 & 8 \\
\hline Crabronidae & 45 & 62 & 131 & 106 & 94 & 78 & 88 \\
\hline Andrenidae & 21 & 45 & 63 & 37 & 53 & 46 & 38 \\
\hline Apidae & 43 & 39 & 56 & 35 & 38 & 46 & 47 \\
\hline Colletidae & 18 & 17 & 22 & 17 & 20 & 22 & 16 \\
\hline Halictidae & 53 & 52 & 66 & 56 & 51 & 50 & 49 \\
\hline Megachilidae & 27 & 23 & 46 & 32 & 36 & 34 & 35 \\
\hline Melittidae & 1 & 5 & 6 & 4 & 4 & 4 & 3 \\
\hline Összesen: & 285 & 314 & 534 & 397 & 303 & 377 & 382 \\
\hline
\end{tabular}

\section{Ritka fajok}

\section{Chrysididae}

Omalus biaccinctus (Buysson, 1893) - Melegkedvelő palearktikus faj. Magyarországon ritka. Az elmúlt évtizedekben Dél-Dunántúl kilenc pontján gyüjtöttük (Külső- és BelsőSomogy, Mecsek), és megtaláltuk Bakony-vidék két helyén is.

\section{Pompilidae}

Agenioideus usurarius (Tournier, 1889) - Ritka nyugat-mediterrán elterjedési jellegü pókölődarázs. Régebben csak két hazai lelöhelyét közölték (MóczÁR L. 1956). Az utóbbi évtizedek faunisztikai kutatásaink nyomán Külső-Somogyban hét lelőhelyen, BelsőSomogyban (Libickozma) továbbá Pécselyen és Simontornyán találtuk meg. DélDunántúlon ez a szentbalázsi lelőhelye a legdélebbi.

Entomobora crassitarsis (Costa, 1887) - Szentbalázs: löszmélyút, 2010. VI. 6. 1 nőstény (leg. Józan Zs.) - Nagyon ritka Észak-Afrikától Lengyelországig előkerült mediterrán elterjedési jellegü faj (Fauna Europaea). Első példányát 1955-ben a Mecsekben 
gyüjtötték (MóczÁr L. 1956). A fentebbi lelöhelyen kívül előkerült Tolnanémedi: Szentpéteri-hegyen, amelyet Malaise csapdával Tóth Sándor is gyüjtött (JózAN 2014, 2018).

Priocnemis pogonioides Costa, 1883 - Szentbalázs: löszmélyút, 2017. VII. 26. 1 nőstény (leg. Józan Zs.). - Nagyon ritka dél-európai pókölődarázs. Olaszország északi részén és Délkelet-Európában kimutatott ritka faj (Bulgária, Görögország), amit megtaláltak Franciaországban is (Fauna Europaea). Hazánkban előkerült még Inotán (Várpalota) is (JózAN 2018).

\section{Crabronidae}

Passaloecus borealis Dahlbom, 1844 - Szentbalázs: löszmélyút, 2016. IX. 3.1 nőstény (leg. Józan Zs). - Európa nagy részén elterjedt faj, melyet Skandináviától Görögországig találtak meg. A Magyar Természettudományi Múzeum gyüjteményében csak a Kárpátok két, egymástól távol eső pontján gyüjtött példányok vannak (BAJÁRI 1957, JózAn 2018).

Passaloecus brevilabris Wolf, 1958 - Szentbalázs: löszmélyút, 2015. V. 30.1 hím (leg. Józan Zs.) - Európában szélesen elterjedt faj, Svédországtól a dél- európai országokig találták meg (Fauna Europaea). Magyarországon az első előfordulását Külső-Somogyból közölték: Gamás, Somogybabod (JózAN 2018). Gyüjtöttük még Kisdobszán (Baranyamegye) is.

Passaloecus pictus Ribaut, 1952 - Szentbalázs: löszmélyút, 2012. V. 10. 3 hím, 2016 IX. 3.2 nőstény, 2018. V. 12. 2 nőstény 2 hím, 2020. VII. 20. 1 hím (leg. Józan Zs.). Dél-Európa és Közép-Európa melegebb klímájú területein elterjedt ritka gyantásdarázs (Fauna Europaea). Hazánkban első előfordulását Kaposvárról és Kaposszerdahelyről ismertették (JózAN 2008). Feltételezhetjük, hogy nálunk terjeszkedő faj. Első hazai példányát 2005-ben fogtuk, majd a következő években megtaláltuk Simontornyán (JózAN 2014) továbbá a Balaton déli területein, a Zselic újabb pontján (Patca) a Bakonyban (Hegymagas) is.

Cerceris bicincta Klug, 1835 - Szentbalázs: löszmélyút, 2014. VI. 23. 1 nőstény (leg. Józan Zs.). - Ritka melegkedvelő, mediterrán elterjedési jellegü csomósdarázs faj. DélDunántúlon csak a Balaton déli területén(Balatonboglár, Balatonszárszó), Nagyharsánynál és Simontornyán gyüjtöttük.

\section{Apidae}

Amegilla magnilabris (Fedtschenko, 1875) - Szentbalázs: löszmélyút, 2019. VIII. 13. 1 hím (leg. Józan Zs.) - Melegkedvelő mediterrán bundásméh faj. Magyarországon túlnyomórészt az Alföldön gyüjtötték, a Dunántúlon csak Nagykapornak lelőhelyét ismertük (Móczár M. 1958a). Az elmúlt évtizedek faunisztikai vizsgálatai során Szentbalázson kívül csak Balatonszemes környékén találtuk meg.

Nomada bispinosa Mocsáry, 1883 - Szentbalázs: löszmélyút, 1979. V. 13. 1 nőstény (leg. Józan Zs.) - A magyarországi Nomadinae fajok faunakatalógusában (MóczÁR \& ScHWARCZ 1968) csak Budapest területéről, Zebegényből és Tolcsváról említik előfordulását. Az elmúlt évtizedekben gyüjtöttük a Zselicben még Nagyberkiben és Kaposvár környékén is. Előkerült még a belső-somogyi Kaposfőn.

Nomada mutabilis Morawitz, 1870 - Szentbalázs: löszmélyút, 1989. VII. 18. 1 nőstény (leg. Józan Zs.) - Melegkedvelő mediterrán nomádméh faj. A 20. század első felében Magyarországon néhány Budapest környéki és alföldi lelőhelyén kívül Szentlörinc környékéröl volt ismert. A szerző a Bakony-vidéken öt lelöhelyen gyüjtötte. A Zselicben négy helyen sikerült kimutatnia, és megtalálta Belső-Somogyban is (Szabás). 
Thyreus histrionicus (Illiger, 1806) - Szentbalázs: löszmélyút, 2013. VIII. 17. 2 nőstény, 2020. VIII. 11. 2 nőstény (leg. Józan \& Sasvári) - Melegkedvelő palearktikus foltosméh. Európában a mediterrán területeken és Közép-Európa melegebb klímájú területein él (Fauna Europaea). Magyarországon néhány régi lelöhelye Budapest környékén, az Alföldön és Dél-Dunántúlon (Nagyharsány, Simontornya) található (MóczÁR M. 1958a). A szerző az elmúlt évtizedekben gyüjtötte a Bakonyban (Bodajk, Alsóőrs), Külső-Somogyban (Kereki), a Zselic egy másik pontján (Simonfa), valamint Pálfán és Pincehelyen. A gazdaállata az Amegilla quadrifasciata és az A. garrula. Itt a löszmélyúton az előbbi faj él.

\section{Halictidae}

Lasioglossum pseudocaspicum (Blüthgen, 1923) - Szentbalázs: löszmélyút, 1979. V. 13. 1 nőstény (leg. Józan Zs.) - Ritka kelet-mediterrán faj. Irodalmi adat szerint (Ebmer 1970) Magyarországon is előkerült, de a Magyar Természettudományi Múzeum gyüjteményében nincs bizonyító példánya. A szerző az elmúlt évtizedek során megtalálta még a Szentbalázshoz közeli Hajmáson, továbbá Taliándörögdön (Déli-Bakony).

\section{Megachilidae}

Coelioxys acanthura Illiger, 1806 - Szentbalázs: löszmélyút, 2015. VIII. 3.1 nőstény (leg. Sasvári M.), 2018. VII. 10. 1 nőstény (leg. Józan Zs.) - Nagyon ritka kakukkméh faj. Lelöhelyei Marokkótól Dél-Európa félszigetein, a Krím-félszigeten, Dagesztánon és Belső-Ázsián át Kínáig találhatók (Discover Life, Fauna Europaea). A Magyar Természettudományi Múzeum gyüjteményben csak néhány 19. század végén gyüjtött példánya található Budapest és Fiume lelőhely megjelöléssel (MóczÁR M. 1958b). Az azóta eltelt száz év során újabb példánya nem került elő, ezért a hazánk faunájából eltünt méhfajok közé soroltuk (JóZAN 2011). Meglepetésünkre 2020. augusztusában egy újabb nőstényét fogtuk meg Nagyberényben (Külső-Somogy) egy régi téglafalon. A szakirodalom szerint a Chalicodoma syraensis a gazdaállata (MóczÁr M. 1958b). A két Somogy-megyei lelőhelyén együtt gyüjtöttük a Megachile albisecta szabóméhhel. Ez méretében megegyezik az előbbi fajjal, tehát bizonyos. hogy ez utóbbi szintén gazdaállata.

Megachile albisecta (Klug, 1817) - Szentbalázs: löszmélyút - Tizenegy alkalommal fogtuk meg 9 nőstény és 13 hím példányát - Magyarországon a múlt évszázad közepéig néhány dunántúli lelőhelyen találták meg (MóczÁR M. 1958b). A szerző az elmúlt évtizedek gyüjtései során kimutatta a Balaton-felvidéken, Külső- és Belső-Somogyban, a Mecsekben, a Velencei-hegységben és a Dunántúli-dombvidék keleti részén is. Ujabban Gebei Lóránt megtalálta a tiszántúli Furtán. A mintegy két tucatnyi lelöhelye ellenére nem mondható gyakorinak. A Coelioxys acanthura gazdaállataként érdemel kiemeltebb figyelmet. 


\section{A gyüjtött fajok jegyzéke}

\section{CHRYSIDOIDEA CHRYSIDIDAE}

Chrysis cingulicornis Förster, 1853

Chrysis distincta Olivier, 1791

Chrysis grohmanni Dahlbom, 1854

Chrysis ignita (Linnaeus, 1758)

Chrysis inaequalis Dahlbom, 1854

Chrysis mediata Linsenmaier, 1951

Chrysis ragusae Destefani, 1888

Chrysis scutellaris Fabricius, 1794

Chrysis solida Haupt, 1957

Chrysis viridula Linnaeus, 1761

Chrysura trimaculata (Förster, 1853)

Trichrysis cyanea (Linnaeus, 1758)

Hedychridium ardens (Couquebert, 1801)

Hedychridium coriaceum (Dahlbom, 1854)

Hedychridium roseum (Rossi, 1790)

Hedychridium valesiense Linsenmaier, 1959

Hedychrum gerstaeckeri Chevrier, 1869

Hedychrum niemelai Linsenmaier, 1959

Hedychrum nobile (Scopoli, 1763)

Hedychrum rutilans (Dahlbom, 1854)

Holopyga generosa (Förster, 1853)

Omalus biaccinctus (Buysson, 1893)

Pseudomalus bidentulus (Lepeletier, 1806)

Pseudospinolia neglecta (Shuckard, 1837)

\section{VESPOIDEA}

MUTILLIDAE

Smicromyrme rufipes (Fabricius, 1787)

Myrmilla calva (Villers, 1789)

\section{SAPYGIDAE}

Sapyga quinquepunctata (Fabricius, 1781)

\section{SCOLIIDAE}

Scolia quadripunctata Fabricius, 1775

\section{TIPHIIDAE}

Tiphia unicolor Lepeletier, 1845

\section{POMPILIDAE}

Agenioideus usurarius (Tournier, 1889)

Anoplius concinnus (Dahlbom, 1845)

Anoplius infuscatus (Vander Linden, 1827)

Anoplius nigerrimus (Scopoli, 1763)

Anoplius viaticus paganus (Dahlbom, 1843)

Anospilus orbitalis (Costa, 1863)

Aporus pollux (Kohl, 1888)

Arachnospila minutula (Dahlbom, 1843)

Arachnospila spissa (Schiödte, 1837)

Arachnospila trivialis (Dahlbom,1843)
Auplopus albifrons (Dalman, 1823)

Auplopus carbonarius (Scopoli, 1763)

Auplopus rectus (Haupt, 1926)

Cryptocheilus notatus affinis (Vander Linden, 1827)

Cryptocheilus versicolor (Scopoli, 1763)

Dicyrtomellus tingitanus (Wolf, 1966)

Dipogon bifasciatus (Geoffroy, 1785)

Entomobora crassitarsis (Costa, 1887)

Evagetes elongatus (Lepeletier, 1845)

Evagetes siculus (Lepeletier, 1845)

Nanoclavelia leucoptera (Dahlbom, 1845)

Priocnemis melanosoma Kohl, 1880

Priocnemis mimula (Wesmael, 1851)

Priocnemis perturbator (Harris, 1776)

Priocnemis pogonioides Costa, 1883

VESPIDAE: VESPINAE

Polistes nimpha (Christ, 1791)

Vespula germanica (Fabricius, 1793)

Vespula vulgaris (Linnaeus, 1758)

\section{VESPIDAE: EUMENINAE}

Alastor mocsaryi (André, 1884)

Ancistrocerus acutus (Fabricius, 1793)

Ancistrocerus gazella (Panzer, 1796)

Antepipona deflenda (Saunders, 1853)

Antepipona orbitalis (Herrich-Schaeffer, 1839)

Eumenes coarctatus (Linnaeus, 1758)

Eumenes coronatus (Panzer, 1799)

Eumenes lunulatus Fabricius, 1804

Eumenes papillarius (Christ, 1791)

Eumenes pedunculatus (Panzer, 1799)

Leptochilus regulus (Saussure,1856)

Microdynerus nugdunensis (Saussure, 1856)

Odynerus reniformis (Gmelin, 1790)

Odynerus spinipes (Linnaeus, 1758)

Stenodynerus bluethgeni v. d. Vecht, 1971

Stenodynerus chevrieranus (Saussure, 1856)

\section{APOIDEA: SPHECIFORMES}

SPHECIDAE

Ammophila campestris Latreille, 1809

Ammophila heydeni Dahbom, 1845

Ammophila sabulosa (Linnaeus, 1758)

Podalonia hirsuta (Scopoli, 1763)

Sceliphron curvatum (Smith, 1870)

CRABRONIDAE: PEMPHREDONINAE

Diodontus brevilabris Beaumont, 1967

Diodontus luperus Shuckard, 1837

Diodontus minutus (Fabricius, 1793) 
Diodontus tristis (Vander Linden, 1829)

Mimumesa dahlbomi (Wesmael, 1852)

Passaloecus borealis Dahlbom, 1844

Passaloecus brevilabris Wolf, 1958

Passaloecus pictus Ribaut, 1952

Pemphredon inornata Say, 1824

Pemphredon lethifera (Shuckard, 1837)

Pemhredon lugens Dahlbom, 1842

Psenulus pallipes (Panzer, 1798)

\section{CRABRONIDAE: ASTATINAE}

Astata boops (Schrank, 1781)

Astata kashmirensis Nurse, 1909

Astata minor Kohl, 1895

CRABRONIDAE: BEMBICINAE

Harpactus affinis (Spinola, 1808)

Nysson trimaculatus (Rossi, 1790)

\section{CRABRONIDAE: CRABRONINAE}

Crossocerus exiguus (Vander Linden, 1829)

Crossocerus ovalis Lepeletier \& Brullé, 1834

Crossocerus quadrimaculatus (Fabricius, 1793)

Ectemnius dives (Lepeletier \& Brullé, 1835)

Lestica clypeata (Schreber, 1759)

Lindenius albilabris (Fabricius, 1793)

Lindenius pygmaeus armatus (Vander Linden, 1829)

Liris nigra (Fabricius, 1775)

Miscophus bicolor Jurine, 1807

Oxybelus quatordecimnotatus Jurine, 1807

Oxybelus victor Lepeletier, 1805

Pison atrum (Spinola, 1808)

Solierella compedita (Piccioli, 1869)

Tachysphex tarsinus (Lepeletier, 1845)

Tachysphex unicolor (Panzer, 1809)

Trypoxylon clavicerum Lepeletier \& Serville, 1828

Trypoxylon figulus (Linnaeus, 1758)

Trypoxylon medium Beaumont, 1945

Trypoxylon scutatum Chevrier, 1867

\section{CRABRONIDAE: PHILANTHINAE}

Cerceris arenaria (Linnaeus, 1758)

Cerceris bicincta Klug, 1835

Cerceris interrupta (Panzer, 1799)

Cerceris quadrifasciata (Panzer, 1799)

Cerceris quinquefasciata (Rossi, 1792)

Cerceris rubida (Jurine, 1807)

Cercerys rybyensis (Linnaeus, 1771)

Cerceris sabulosa (Panzer, 1799)

Philanthus triangulum (Fabricius, 1775)

APOIDEA: ANTHOPHILA

ANDRENIDAE

Andrena bimaculata (Kirby, 1802)

Andrena cineraria (Linnaeus, 1758)
Andrena curvana Warncke, 1965

Andrena curvungula Thomson, 1870

Andrena dorsata (Kirby, 1802)

Andrena falsifica Perkins, 1915

Andrena flavipes Panzer, 1799

Andrena floricola Eversmann, 1852

Andrena gravida Imhoff, 1832

Andrena hattorfiana (Fabricius, 1775)

Andrena labialis (Kirby, 1802)

Andrena lagopus Latreille, 1809

Andrena limata Smith, 1853

Andrena marginata Fabricius, 1776

Andrena minutula (Kirby, 1802)

Andrena nitida (Müller, 1776)

Andrena ovatula (Kirby, 1802)

Andrena subopaca Nylander, 1848

Andrena susterai Alfken, 1914

Andrena taraxaci Giraud, 1861

Panurgus calcaratus (Scopoli, 1763)

\section{APIDAE}

Amegilla magnilabris (Fedtschenko, 1875)

Amegilla quadrifasciata (Villers, 1789)

Amegilla salviae (Morawitz, 1856)

Anthophora crinipes Smith, 1854

Anthophora plagiata (Illiger, 1806)

Anthophora plumipes (Pallas, 1772)

Anthophora pubescens (Fabricius, 1781)

Biastes brevicornis (Panzer, 1798)

Bombus pascuorum (Scopoli, 1763)

Bombus sylvarum (Linnaeus, 1761)

Bombus terrestris (Linnaeus, 1758)

Ceratina chalybea Chevrier, 1872

Ceratina cucurbitina (Rossi, 1792)

Ceratina cyanea (Kirby, 1802)

Ceratina nigrolabiata Friese, 1896

Eucera nigrescens Pérez, 1879

Melecta albifrons (Foerster, 1771)

Nomada alboguttata Herrich-Schaeffer, 1839

Nomada bifasciata Olivier, 1811

Nomada bispinosa Mocsáry. 1883

Nomada bluethgeni Stöckhert, 1943

Nomada distinguenda Morawitz, 1874

Nomada fabriciana (Linnaeus, 1767)

Nomada flavoguttata (Kirby, 1802)

Nomada flavopicta (Kirby, 1802)

Nomada fucata Panzer, 1798

Nomada fulvicornis Fabricius, 1793

Nomada fuscicornis Nylander, 1848

Nomada goodeniana (Kirby, 1802)

Nomada lathburiana (Kirby, 1802)

Nomada marshamella (Kirby, 1802)

Nomada mutabilis Morawitz, 1870

Nomada rhenana Morawitz, 1872

Nomada sexfasciata Panzer, 1799 
Nomada sheppardana (Kirby, 1802)

Nomada succincta Panzer, 1798

Nomada trispinosa Schmiedeknecht, 1883

Nomada zonata Panzer, 1798

Pasites maculatus Jurine, 1807

Tetraloniella nana (Morawitz, 1873)

Thyreus histrionicus (Illiger, 1806)

Thyreus ramosus (Lepeletier, 1841)

Triepeolus tristis (Smith, 1804)

\section{COLLETIDAE}

Colletes cunicularius (Linnaeus, 1761)

Colletes hylaeiformis Eversmann, 1852

Colletes inexpectatus Noskiewitz, 1936

Colletes similis Schenck, 1859

Hylaeus angustatus (Schenck, 1859)

Hylaeus annularis (Kirby, 1802)

Hylaeus brevicornis Nylander, 1852

Hylaeus communis Nylander, 1852

Hylaeus confusus Nylander, 1852

Hylaeus difformis (Eversmann, 1852)

Hylaeus duckei (Alfken, 1904)

Hylaeus gibbus Saunders, 1850

Hylaeus hyalinatus Smith, 1842

Hylaeus leptocephalus (Morawitz, 1870)

Hylaeus kahri Förster, 1871

Hylaeus signatus (Panzer, 1798)

Hylaeus sinuatus (Schenck, 1853)

Hylaeus variegatus (Fabricius, 1798)

\section{HALICTIDAE}

Halictus asperulus Pérez, 1895

Halictus eurygnathus Blüthgen, 1931

Halictus kessleri Bramson, 1879

Halictus langobardicus Blüthgen, 1944

Halictus maculatus Smith, 1848

Halictus quadricinctus (Fabricius, 1776)

Halictus rubicundus (Christ, 1791)

Halictus scabiosae (Rossi, 1790)

Halictus sexcinctus (Fabricius, 1775)

Halictus subauratus (Rossi, 1792)

Lasioglossum albipes (Fabricius, 1781)

Lasioglossum bluethgeni Ebmer, 1971

Lasioglossum brevicorne (Schenck. 1869)

Lasioglossum calceatum (Scopoli, 1763)

Lasioglossum costulatum (Kriechbaumer, 1873)

Lasioglossum glabriusculum (Morawitz, 1872)

Lasioglossum interruptum (Panzer, 1798)

Lasioglossum laticeps (Schenck, 1869)

Lasioglossum lativentre (Schenck, 1853)

Lasioglossum leucozonium (Schrank, 1781)

Lasioglossum malachurum (Kirby, 1802)

Lasioglossum marginatum (Brullé, 1832)

Lasioglossum marginellum (Schenck, 1853)

Lasioglossum minutissimum (Kirby, 1802)
Lasioglossum morio (Fabricius, 1793)

Lasioglossum nigripes (Lepeletier, 1841)

Lasiogossum nitidiusculum (Kirby, 1802)

Lasioglossum nitidulum (Fabricius, 1804)

Lasioglossum parvulum (Schenck, 1853)

Lasiogossum pauxillum (Schenck, 1853)

Lasioglossum politum (Schenck, 1853)

Lasioglossum pseudocaspicum (Blüthgen, 1923)

Lasioglossum punctatissimum (Schenck, 1853)

Lasioglossum puncticolle (Morawitz, 1872)

Lasioglossum quadrinotatum (Kirby, 1802)

Lasioglossum trichopygum (Blüthgen, 1923)

Lasioglossum villosulum (Kirby, 1802)

Nomiapis diversipes (Latreille, 1806)

Sphecodes albilabris (Fabricius, 1793)

Sphecodes crassus Thomson, 1870

Sphecodes ephippius (Linnaeus, 1867)

Sphecodes ferruginatus Hagens, 1882

Sphecodes gibbus (Linnaeus, 1758)

Sphecodes longulus Hagens, 1882

Sphecodes majalis Pérez, 1903

Sphecodes miniatus Hagens, 1882

Sphecodes monilicornis (Kirby, 1802)

Sphecodes niger Hagens, 1874

Sphecodes pellucidus Smith, 1845

Sphecodes puncticeps Thomson, 1870

Sphecodes rufiventris (Panzer, 1798)

Systropha curvicornis (Scopoli, 1770)

Systropha planidens Giraud, 1861

\section{MEGACHILIDAE}

Anthidium manicatum (Linnaeus, 1758)

Anthidium oblongatum (Illiger, 1806)

Anthidium strigatum (Panzer, 1805)

Chelostoma campanularum (Kirby, 1802)

Chelostoma distinctum (Stöckhert, 1929)

Chelostoma rapunculi (Lepeletier, 1841)

Coelioxys acanthura Illiger, 1806

Coelioxys afra Lepeletier, 1841

Coelioxys conoidea (Illiger, 1806)

Coelioxys elongata Lepeletier, 1841

Coelioxys inermis (Kirby, 1802)

Heriades truncorum (Linnaeus, 1758)

Hoplitis leucomelana (Kirby, 1802)

Hoplitis tergestensis (Ducke, 1897)

Hoplosmia bidentata (Morawitz, 1876)

Hoplosmia spinulosa (Kirby, 1802)

Megachile albisecta (Klug, 1817)

Megachile ericetorum Lepeletier, 1841

Megachile pilidens Alfken, 1924

Megachile rotundata (Fabricius, 1787)

Megachile versicolor Smith, 1844

Megachile willughbiella (Kirby, 1802)

Osmia aurulenta (Panzer, 1899)

Osmia caerulescens (Linnaeus, 1758) 
Osmia rufa (Linnaeus, 1758)

Osmia rufohirta Latreille, 1811

Trachusa byssina (Panzer, 1798)
MELITTIDAE

Dasypoda hirtipes (Fabricius, 1793)

\section{Irodalom}

BAJÁRI E. 1957: Kaparódarázs alkatúak I. - Sphecoidea I. - in: Magyarország Állatvilága (Fauna Hungariae) XIII/7: 1-117.

Ebmer, A. W. 1970: Die Bienen des Genus Halictus s.l. im Grossraum von Linz (Hymenoptera, Apidae), II. - in: Naturkundliches Jahrbuch der Stadt Linz 16: 12-82.

Józan Zs. 2008: Új kaparódarázs fajok (Hymenoptera, Sphecidae) Magyarország faunájában. - Somogyi Múzeumok Közleményei 18: 81-83.

JóZAN, Zs. 2011: Checklist of Hungarian Sphecidae and Apidae species (Hymenoptera, Sphecidae and Apidae). - Natura Somogyiensis 19: 177-200. https://doi.org/10.24394/NatSom.2011.19.177

JózAN Zs. 2014: Adatok Simontornya fullánkos (Hymenoptera, Aculeata) faunájához. - in: Simontornya ízeltlábúi - in memoriam Pillich Ferenc pp. 117-129.

JózAN Zs. 2018: Újabb adatok Somogy megye fullánkos hártyásszárnyú (Hymenoptera: Aculeata) faunájához. - Natura Somogyiensis 32: 133-146. https://doi.org/10.24394/NatSom.2018.32.133

MóczÁR L 1956: Pókölődarázs alkatúak - Pompiloidea. In: Magyarország Állatvilága (Fauna Hungariae) $\mathrm{XIII} / 5: 1-76$.

MóczÁr M. 1958a: A bundásméhek (Anthophora Latr.) és fészekélősködőik, a gyász és foltosméhek (Melecta Latr., Crocisa Latr.) revíziója, fanakatalógusa és etológiai adatasi. - Folia entomologica hungarica 11: 403-421.

MóczÁr, M. 1958b: Művészméhek - Megachilidae. - Magyarország Állatvilága (Fauna Hungariae), XIII/12: $1-78$.

MóczÁr, L. 1960: Az Odynerus spiricornis Spin. (Hym. Eumen.) tevékenysége. - Állattani Közlemények 47(3-4): 119-125.

MóczÁR, L. 1961: Kísérletek Odynerus spiricornis Spin.-nal (Hymenoptera, Eumenidae). - Állattani Közlemények 48(1-4): 91-94.

MóczÁr, L. \& Schwarcz, M. 1968: A Nomada-, Ammobates-, Pasites és Parammobatodes nemek faunakatalógusa (Cat. Hym. XXIII.). - Folia entomologica hungarica 23: 209-219.

\section{websites}

Discover Life bee species guide and world checklist, Ascher and Pickering. - www.discoverlife.org $/ \mathrm{mp} / 20 \mathrm{q}$ - last accessed 20. 10. 2020.

Fauna Europaea: All European animal species online. - https://fauna-eu.org /cdm_dataportal/taxon - last accessed 20. 10. 2020. 